\title{
Subcellular localization of the "classic" s I00 subunits in vestibular end organs of the rat
}

\begin{abstract}
Using immunohistochemical techniques, the distribution of the "classic" S100 calcium binding proteins, $\alpha$ (A1) and $\beta$ (B), was determined in the mammalian vestibular end organs. An affinity-purified polyclonal antibody which recognized both the A1 and $\mathrm{B}$ subunits and two monoclonal antibodies specific for either the A1 or the B subunit were used in this study. S100A1 was localized specifically to the basal region of the sensory epithelium (saccular macula, cristae ampullaris and utricular macula) when a cross-linking fixative ( $4 \%$ paraformaldehyde) was utilized. Using a fixation protocol including paraformaldehyde and a precipitating fixative revealed an additional localization of S100A1 to the apical region of the saccular macula, cristae ampullaris and utricular macula. This indicates the presence of two populations of S100A1 in these cells: a cytosolic (soluble) component; and a membrane-bound fraction. In contrast, S100B was localized to the layer of the vestibular nerve fibers. Immunoreactivity for S100B was not observed in the sensory epithelium of the saccular or utricular macula or in the cristae ampullaris. The preferential distribution of S100B to the nerve fibers and S100A1 to cells of the sensory epithelium, in two forms (cytosolic and membranebound), may be important in the functional roles of S100 proteins in the vestibular sensory end organs.
\end{abstract}

Keywords: s100 proteins, calcium, hair cells, vestibular, immunohistochemistry
Volume 4 Issue 5 - 2017

\author{
James D Foster \\ Division of Anatomy and Molecular Medicine,Alabama College \\ of Osteopathic, USA
}

Correspondence: James D Foster, Division of Anatomy and Molecular Medicine, Alabama College of Osteopathic, 445 Health Sciences Boulevard, Dothan, Alabama, 36303, USA, Tel (334) 944-40I2, Fax (334) 944-2268,

Email jfoster@acomedu.org

Received: October 28, 2017 | Published: November 28, 2017

\section{Introduction}

S100 proteins are acidic low molecular weight members of a family of calcium-binding proteins that were originally identified in the nervous system, ${ }^{1,2} \mathrm{~S} 100$ proteins have since been localized to several neuronal and non-neuronal cells, including adrenal chromaffin cells and skeletal muscle cells, in addition to glial cells and neurons. ${ }^{3}$ The two "classic" S100 proteins were given the designation $\alpha$ and $\beta$. Since, these two S100 proteins tended to form homo- or heterodimers with each other; they were described as "subunits" of S100. Related to their apparent function, these proteins have been reported to be closely associated with cytoskeletal proteins. ${ }^{3}$ These "classical" S100 proteins exist in three dimeric forms (S100a $[\alpha \alpha], \mathrm{S} 100 \mathrm{ao}[\alpha \beta]$ and S100b $[\beta \beta])$. To fit in with the current nomenclature for S100 proteins, the $\alpha$ subunit is referred to as $\mathrm{S} 100 \mathrm{~A} 1$ and the $\beta$ subunit is now designated S100B. ${ }^{4}$ Since their initial identification, several other S100-related proteins with high degrees of structural homology to the S100A1 and/ or S100B have been identified and are included as members of the S100 family. ${ }^{3,4}$ A large group of S100 proteins that have similarities to S100A1 are clustered on the 1q21 loci of chromosome 1 in the human ${ }^{5,6}$ and were named according to their spatial placement on this loci. Ridenger et al. ${ }^{6}$ have also identified a similar distribution of many of the S100 proteins on mouse chromosome 3. The gene for S100B is located on human chromosome $21 .^{7}$ The relationship of S100 to human brain disorders is supported by the finding that there is an increase in the level of S100B in the amniotic fluid in trisomy-21 fetuses, ${ }^{8}$ the number of glial cells expressing S100B is increased in patients with trisomy 21 (Down's syndrome $)^{9,10}$ as well as in patients with certain forms of Alzheimer's disease ${ }^{11,12}$ associated with similar genetic defects on chromosome 21. Most of the S100 proteins identified on human chromosome 1 have been named using S100A plus a number to identify its location on chromosome 1 (e.g., S100A1, S100A2, etc.). Some examples of these other S100 proteins include S100A2 identified in the lungs, kidney ${ }^{4}$ and cartilage, ${ }^{13}$ S100A4, A6 and A10 in fibroblasts, ${ }^{14}$ and S100A7-A10 in epithelial cells. ${ }^{15,16}$ Although the apparent typical location of S100 proteins is either plasma membranebound or cytoplasmic, the S100A6 protein has been localized with annexin II to the nuclear envelope of smooth muscle cells. ${ }^{17}$ S100A6 has also been reported to be associated with subpopulation of neurons and glial cells. ${ }^{18}$

S100 proteins have been implicated as modulators of $\mathrm{Ca}^{2+}$ dependent processes, such as secretion/neurotransmission ${ }^{19-21}$ and intracellular $\mathrm{Ca}^{2+}$ release. ${ }^{22}$ In addition, $\mathrm{S} 100$ proteins, in particular S100B, may be related to tissue development, repair and regeneration, ${ }^{23}$ the process of learning and memory ${ }^{24}$ and appear to play a role in central nervous system development and pathologies. ${ }^{9-12}$ In addition to Down's syndrome and Alzheimer's disease, S100B is also over expressed in children with cerebral palsy ${ }^{25}$ and has been implicated in schizophrenia ${ }^{26}$ and affective disorders. ${ }^{27}$ Treatment with antidepressants also results in increased levels of S100B mRNA in mouse hippocampus. ${ }^{28}$ Serotonin action during central nervous system development has been shown to be mediated by S100B, ${ }^{29}$ and serotonin release during exercise is associated with a concurrent increase in serum S100B levels. ${ }^{30}$ It is clear from these studies that $\mathrm{S} 100 \mathrm{~B}$ is associated with central nervous system nerve cell maturation and function. S100B and S100A1 have also been localized to the peripheral nervous system. ${ }^{31}$ 
In non-neuronal tissues, S100B and S100A1 are involved in the proper function and development of a variety of tissues. ${ }^{16-35}$ The distribution of S100B and S100A1 has been categorized in a number of non-neuron tissues. ${ }^{36}$ It was observed that S100A1 localization appeared to be associated with secretory cells of exocrine glands. In contrast, S100B was localized to ductal cells or myoepithelial cells in these same glands. They suggested that $\mathrm{Ca}^{+2}$-induced secretion may be mediated by S100A1. In the nervous system, S100A1 may have a similar function in $\mathrm{Ca}^{+2}$ mediated neurotransmitter release. Haimoto's ${ }^{36}$ group also found S100A1 associated with columnar cells of several stratified columnar epithelia. S100B was found in the cytoplasm of basal cells. They proposed that basal cell differentiation into columnar cells may involve a switch from S100B to S100A1 expression. A differential expression of these two S100 proteins in the vestibular end organs may also indicate a similar function in directing normal hair cell function or developmental changes. These proteins, upon binding free intracellular calcium, may modulate calcium-associated events by regulating intracellular calcium levels or by directly interacting with specific intracellular proteins. Using immunohistochemical techniques, we report the cellular distribution of S100A1 and S100B in vestibular end organs of the rat (saccular and utricular maculae, and crista ampullaris).

\section{Materials and methods}

\section{Tissue isolation and processing}

Labyrinthine structures of CD rats (Charles River Laboratories, Wilmington, MA), 18-21days old, were fixed by vascular perfusion with $4 \%$ paraformaldehyde in $0.1 \%$ acetate buffer at $\mathrm{pH} 6$, followed by $4 \%$ paraformaldehyde in $0.1 \mathrm{M}$ borate buffer at $\mathrm{pH} 11$. Fixation continued overnight at $4{ }^{\circ} \mathrm{C}$. Some tissues were fixed in a precipitating fixative to stabilize soluble proteins which can be lost during fixation in formaldehyde. ${ }^{37}$ This precipitating fixative contained $4 \%$ paraformaldehyde, $2 \%$ trichloroacetic acid (TCA), $2 \%$ zinc chloride and $20 \%$ isopropanol. The temporal bones were removed and labyrinthine tissues (cochlea, vestibule and semicircular canals) and perfused with the same fixative introduced through the oval window. The inner ear tissues were immersed in fixative for an additional hour at $4^{\circ} \mathrm{C}$ and then decalcified in a $3 \%$ ethylenediaminetetraacetic acid (EDTA) solution over 5 to 7 days at $4{ }^{\circ} \mathrm{C} .{ }^{38}$ The tissues were then either infiltrated with chilled phosphate-buffered, graded (10\%-20\%$30 \%$ ) sucrose solutions, embedded in O.C.T. embedding medium (a water soluble embedding medium containing polyvinyl alcohol and polyethylene glycol used with frozen tissues; Miles, Elkhart, IN) and sectioned at $10-20 \mu \mathrm{m}$ with a cryostat. Alternatively tissues were dehydrated in graded ethanol, cleared with xylene, embedded in paraffin at $56-58{ }^{\circ} \mathrm{C}$ and sectioned at $6 \mu \mathrm{m}$ with a histological microtome. Sections were deparaffinized using xylene and rehydrated in a series of graded alcohol washes $(100 \%, 90 \%, 70 \%)$ and distilled water. For both techniques, the tissue blocks were oriented with the plane of section parallel to the long axis of the modiolus. Such an orientation allows one to visualize in the same section the basal and apical turns of the cochlea, vestibular structures (saccule, utricle and cristae ampullares), and peripheral processes and cell bodies of the cochlear and vestibular nerves.

\section{Immunohistochemistry}

For immunofluorescence detection, slides containing paraffin sections were rehydrated with $0.01 \mathrm{M}$ phosphate-buffered saline at $\mathrm{pH} 7.4$ (PBS) for 15minutes at room temperature, and some slides were counter-stained with $0.025 \%$ crystal violet in methanol for 2-5minutes to eliminate autofluorescence. After the sections were washed with PBS, they were treated for 15 minutes with a PBS and $0.1 \%$ Triton X-100 solution to enhance primary antibody penetration. $1 \%$ goat serum in PBS was then applied to sections for 10minutes to block non-specific labeling. They were then incubated overnight in primary antibody at $4{ }^{\circ} \mathrm{C}$. The primary antibodies (mouse monoclonal antibodies raised against either purified $\mathrm{S} 100 \mathrm{~A} 1(\alpha$ subunit) or purified S100B ( $\beta$ subunit), and a rabbit polyclonal antibody which recognized both S100A1 and B were used in this study; Sigma Immuno Chemical Co., St. Louis, MO) were diluted with Zymed antibody reagent (Zymed Co., San Francisco, CA) at dilutions of 1:3000, 1:1000, and $1: 1000$, respectively. Following overnight incubation with the primary antibody, sections were washed with PBS and incubated with a FITC goat anti-rabbit IgG or FITC goat anti-mouse (Zymed, SanFrancisco, $\mathrm{CA})$, respectively, for 1 hour at room temperature, rinsed in PBS, and mounted in Vectashield (Vector Laboratories, Inc., Burlingame, CA) or in a PBS solution containing $0.1 \%$ p-phenylenediamine and $70 \%$ glycerol. Slides were examined and photographed by bright field or epifluorescence using a Nikon microscope. The primary antibody was deleted from the incubation medium as a control for staining specificity.

\section{Western blot analysis}

To characterize the specificity of the $\mathrm{S} 100$ antibodies, we used western blot analysis with purified S100B (Bovine S100B; Research Diagnostics, Inc., Flanders NJ). The purified antigen was dissolved in buffer containing $2 \%$ SDS, $10 \%$ glycerol, $0.05 \%$ mercaptoethanol, and $0.0025 \%$ bromophenol blue, and $0.0625 \mathrm{M}$ Tris $\mathrm{HCl}, \mathrm{pH} 6.8$. Samples in sample buffer were vortexed and immersed in a boiling water bath for $90 \mathrm{sec}$ to denature proteins. The antigen $(30 \mu \mathrm{g}$ of $\mathrm{S} 100 \mathrm{~B} / \mathrm{lane})$ was separated on an SDS/PAGE (12.5\% acrylamide gel) in a Biorad Mini-protease II dual slab-cell apparatus (Bio-Rad Laboratories, Richmond, CA). The samples were transferred onto a nitrocellulose membrane overnight in $25 \mathrm{mM}$ Tris, $0.2 \mathrm{mM}$ glycine, and 20\% methanol. Membranes were blocked for $1 \mathrm{hr}$ in Tris-buffered saline (TBS) containing $8 \%$ non fat milk powder and were probed with the polyclonal antibody directed against both S100A1 and B, and the monoclonal antibodies specific for either S100B or S100A1 (see above). The membranes were then washed in TBS and $0.2 \%$ Tween- 20 and incubated with peroxidase goat anti-rabbit IgG or peroxidase horse anti-mouse IgG (Vector Laboratories, Inc., Burlingame, CA) diluted $1: 1000)$ for $1 \mathrm{hr}$ at room temperature. The peroxidase reactivity will be visualized using $0.5 \mathrm{mg} / \mathrm{ml}$ of diaminobenzidine in TBS and $1 \mu 1 /$ $\mathrm{ml}$ of $30 \% \mathrm{H}_{2} \mathrm{O}_{2}$. Prestained low molecular weight markers (SigmaAldrich Corp. St. Louis, MO) were run along with antigen samples to estimate protein size. The molecular weight of monomeric S100B is about $10-12 \mathrm{kDa} .{ }^{14}$ The experiments involving the use of animals in this study were approved by the Animal Investigation Committee of Western University of Health Sciences.

\section{Results}

When sections of the crista ampullaris were fixed with the precipitating fixative, S100A1B immunoreactivity was distributed throughout the apical and basal portions of the epithelium and also within the vestibular nerve fibers (Figure 1). The distribution of immunoreactivity for each subunit was the same in vestibular end organs obtained from the macula of the saccule and utricle (Figure 2 ). When sections of the vestibular end organs were fixed with 
paraformaldehyde or the precipitating fixative (Figure 3; crista ampullaris), S100B immunoreactivity localized to components of the vestibular nerve fibers. When sections of the vestibular end organs were fixed with $4 \%$ paraformaldehyde (Figure 4; crista ampullaris), S100A1 immunoreactivity was localized to the basal region of vestibular epithelium of the crista ampullaris and the utricular maculae. Fixation with the precipitating fixative, revealed a different pattern of localization. Not only was the basal area immunoreactive, but the apical regions of the epithelium in the vestibular end organs were also positive for S100A1 (Figure 5; crista ampullaris). No immunoreactivity was detected in control sections of crista ampullaris incubated with secondary antibody only (Figure 6). The distribution of $\mathrm{S} 100 \mathrm{~A} 1$ and $\mathrm{S} 100 \mathrm{~B}$ is summarized in Tables $1 \& 2$. Incubation of the vestibular ganglion with the antibody to the S100A1B (data not shown) or S100B (Figure 7) revealed immunoreactivity distributed throughout the area of the vestibular ganglion. Regardless of the fixation protocol used, there was no immunoreactivity for S100A1 in any component of the vestibular ganglion (Figure 8). Specificity of the antibodies to S100 subunits was tested on Western blots (immunoblots) performed on purified S100B antigen. The antibodies raised against $\mathrm{S} 100 \mathrm{~B}$ and the mixture of S100A1B reacted with the purified S100B protein. The antibody specific for S100A1was very weakly cross-reactive with the purified S100B protein (Figure 9). Thus, the S100A1B and S100B antibodies were specific for the S100B subunit and the S100A1 antibody did not show appreciable affinity for the S100B subunit.

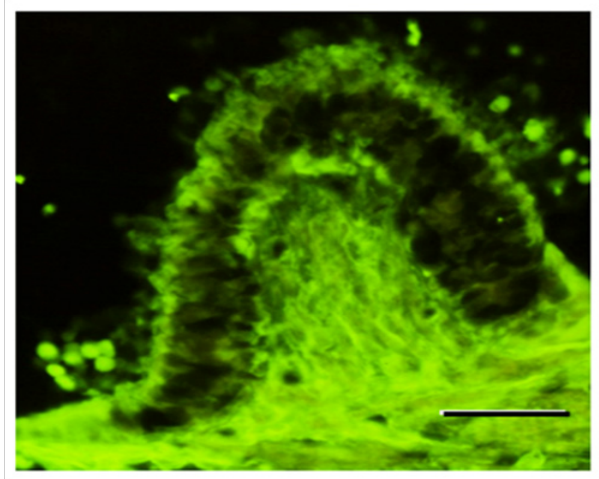

Figure I Section of the crista ampullaris fixed with purfix. SI00AIB immunoreactivity distributed throughout the apical and basal portions of the epithelium and also within the vestibular nerve fibers. Bar, $50 \mu \mathrm{m}$.

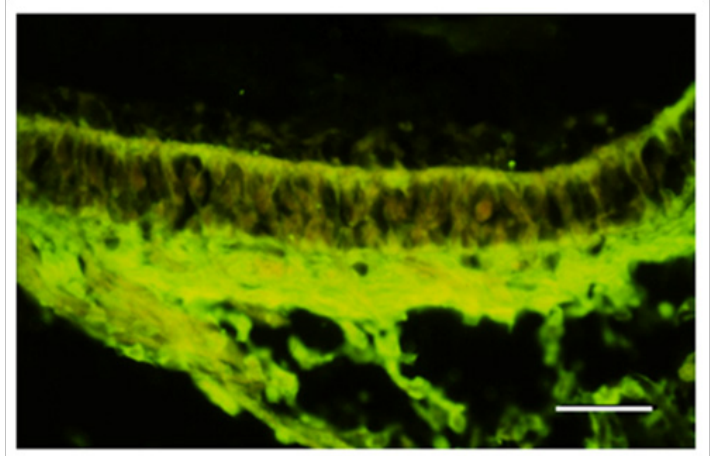

Figure 2 Section through the macula of the utricle. SI00AIB distributed in the apical region of the hair cell and distributed in area of the nerve fibers. Bar, $50 \mu \mathrm{m}$.

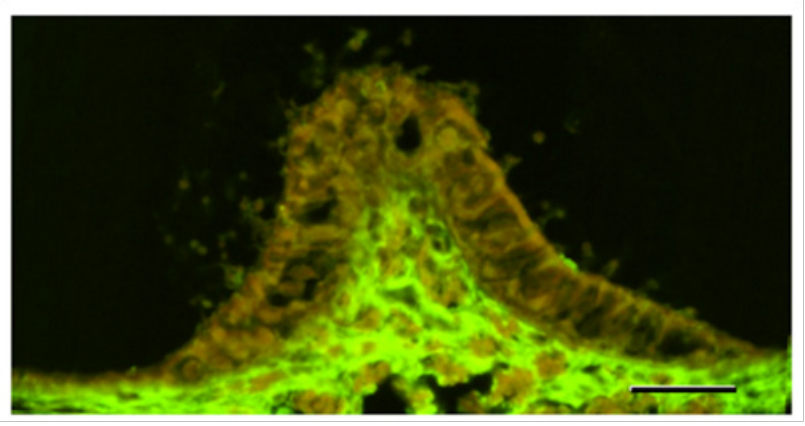

Figure 3 Section of the crista ampullaris fixed with the precipitating fixative. SIOOB immunoreactivity localized to the vestibular nerve fibers. Bar, $50 \mu \mathrm{m}$.

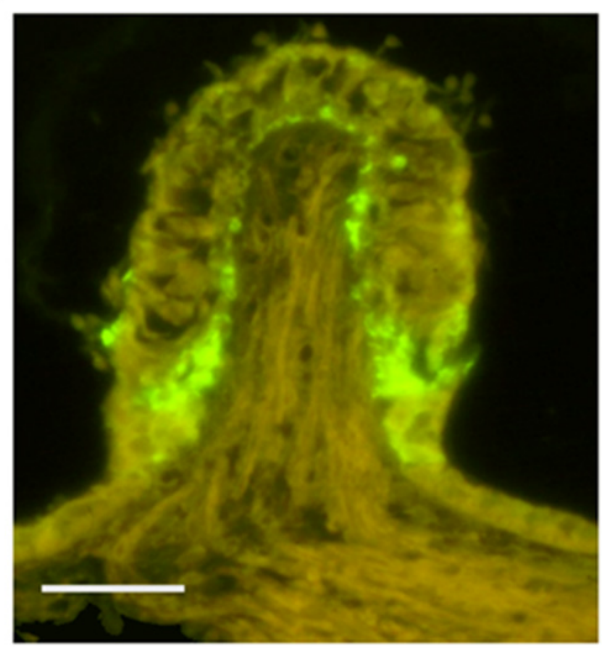

Figure 4 Section of the crista ampullaris fixed with $4 \%$ paraformaldehyde. SIO0AI immunoreactivity localized in basal region of vestibular epithelium of the crista ampullaris. Bar, $50 \mu \mathrm{m}$.

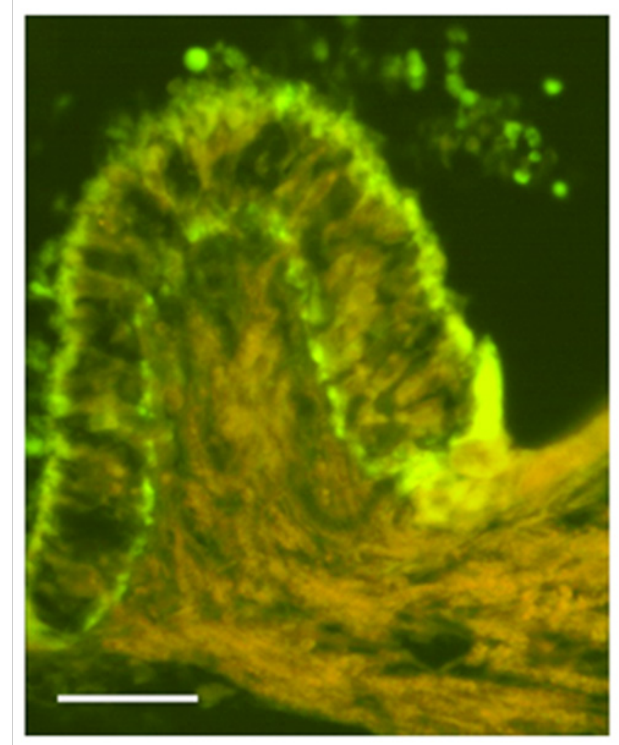

Figure 5 Section of the crista ampullaris fixed with the precipitating fixative. SIOOB immunoreactivity localized in the basal and apical region of the vestibular epithelium of the cristae ampularis. Bar, $50 \mu \mathrm{m}$. 


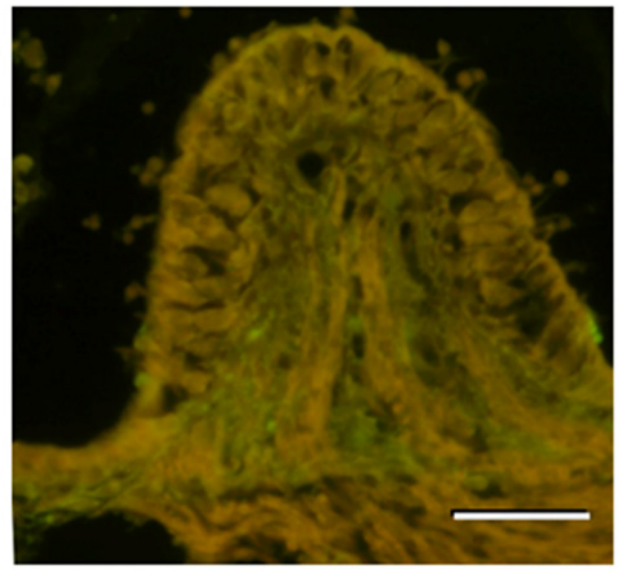

Figure 6 Control section of crista ampullaris. No immunoreactivity detected (minimal non- specific staining in the region of the nerve fibers). Bar, $50 \mu \mathrm{m}$.

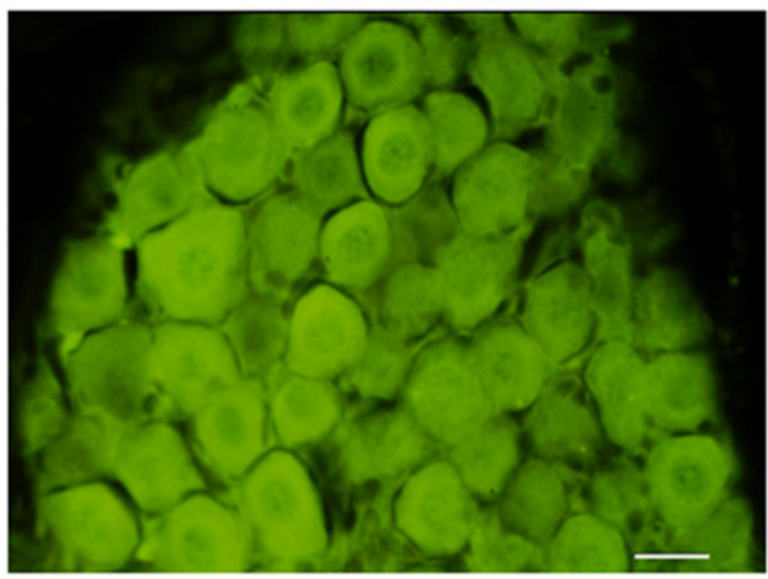

Figure 7 Section of the vestibular ganglion. SIOOB immunoreactivity distributed throughout the area of the ganglion. Bar, I0 $10 \mathrm{~m}$.

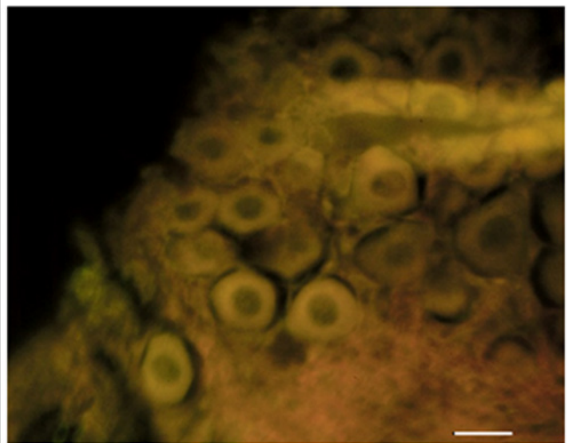

Figure 8 Control section of the vestibular ganglion. There was no immunoreactivity of SIOOAI present within the region of the ganglion. Bar, $10 \mu \mathrm{m}$.

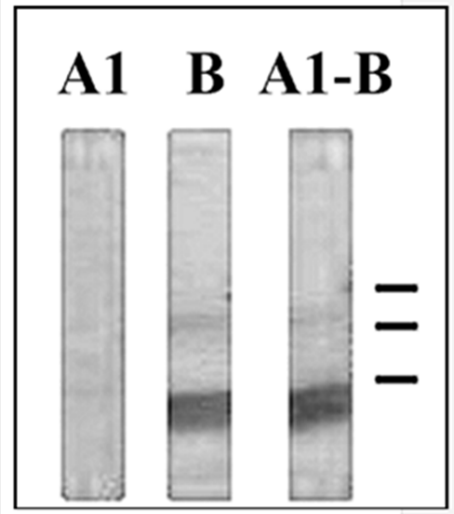

Figure 9 Western blot (immunoblot) was performed on raw purified SI00B antigen. It was reacted with antibodies to either SIO0AI (AI) or SIOOB (B), and or to both SIO0AI and B (AI-B). Two bands were stained with either antibody that recognized SIOOB. One band was at $\sim 10 \mathrm{kDa}$ and the other was $\sim 20 \mathrm{kDa}$. The lower molecular weight band corresponded to the molecular weight on the monomeric form of SIOOB while the higher molecular weight band corresponded to the expected weight of the homodimer of this protein The antibody to SIOOAI did not appear to bind to the SIOOB antigen.

Table I Distribution of SI00 Proteins in the Vestibular End Organs. This table summarizes the distribution of the SI00 subunits in the vestibular end organs

\begin{tabular}{|c|c|c|c|c|c|c|}
\hline & \multicolumn{2}{|l|}{ Anti-S100A1 } & \multicolumn{2}{|l|}{ Anti-S100B } & \multicolumn{2}{|c|}{ Anti-S100A1 and B } \\
\hline & Epithelial cells & $\begin{array}{l}\text { Vestibular } \\
\text { ganglion }\end{array}$ & Epithelial cells & $\begin{array}{l}\text { Vestibular } \\
\text { ganglion }\end{array}$ & $\begin{array}{l}\text { Epithelial } \\
\text { cells }\end{array}$ & $\begin{array}{l}\text { Vestibular } \\
\text { ganglion }\end{array}$ \\
\hline Paraformaldehyde & + & - & - & + & + & + \\
\hline Precipitating Fixative & + & - & - & + & + & + \\
\hline
\end{tabular}

Table 2 Effect of Fixation Protocol on the Distribution of SI00 Proteins in Vestibular Epithelial Cells. This table summarizes the distribution pattern of the SI00 subunits within the epithelial cells of the vestibular end organs obtained from the two different fixation protocols

\begin{tabular}{|c|c|c|c|c|c|c|}
\hline & \multicolumn{2}{|l|}{ Anti-S100A1 } & \multicolumn{2}{|l|}{ Anti-S100B } & \multicolumn{2}{|c|}{ Anti-S100A1 and B } \\
\hline & Basal region & Apical region & Basal region & Apical region & Basal region & Apical region \\
\hline Protocol: Paraformaldehyde & + & - & - & - & + & - \\
\hline Precipitating Fixative & + & + & - & - & + & + \\
\hline
\end{tabular}




\section{Discussion}

In previous studies, we identified the presence of immunohistochemical staining for S100 in vestibular hair cells of the trout and mammals. ${ }^{39,40}$ The results of these two studies were based on the use of a polyclonal antibody that recognized antigenic sites common to both S100A1 and S100B. Therefore, the sites of immunocytochemical reaction identified could be due to the presence of either one or both S100 subunits. Since different functions have been ascribed to S100A1 and S100B in other systems, we identified the distribution of the two "Classic" S100 proteins, S100A1 and $\mathrm{S} 100 \mathrm{~B}$ in the vestibular end organs of the rat. The presence of these S100 proteins suggests a role for S100 in hair cell-related functions, such as modulation of sensory transduction or regeneration of hair cells in response to injury.

\section{General distribution of "classic" SI 00 proteins}

When sections of the vestibular end organs, crista ampullaris, and the maculae of the saccule and utricle, were fixed with the precipitating fixative or the cross linking fixative (paraformaldehyde), immunoreactivity for S100 protein was distributed throughout the apical and basal portions of the vestibular epithelium and also vestibular nerve fibers. This is consistent with results from our earlier studies..$^{40}$ To further address the involvement of S100 proteins in vestibular end organ functions, we identified the two individual "classic" S100 proteins.

\section{Distribution of SIOOB}

When we identified the immunoreactivity for S100B in vestibular end organs, we found that it was confined mainly to components of the vestibular nerve fibers. This is consistent with S100B location in a number of other nervous system locations. For instance, S100B was found associated with ensheathing cells of the rat olfactory pathway during development, ${ }^{41}$ peripheral glial cells of the human fetal cochlea, ${ }^{42}$ satellite cells of sensory, sympathetic and enteric ganglia, and in supporting cells of the adrenal medulla, myelinating and nonmyelinating Schwann cells. ${ }^{31}$ Peripheral neurons express both S100A1 and $\mathrm{B}$, while the dorsal root ganglion contained S100B in the human peripheral nervous system.

\section{Influence of SIOOB on cell development and proliferation}

Taken together, these findings of association of S100B with cells of the nervous system suggest a role for this protein in nervous system development. This assertion may have implications for a functional role of S100B (or S100A1) in vestibular hair cells. Further evidence of the involvement of S100B in neuronal and nervous system development has come from data obtained in several studies. S100B has been found to be associated with neuronal and glial cells in the central and peripheral nervous systems..$^{43}$ Neurite extension is induced by addition of S100B to dissociated cultures of embryonic chick telencephalic neurons, ${ }^{43}$ serotonergic neurons of mesencephalic raphe, ${ }^{44}$ cells of optic tectum ${ }^{45}$ and cells of dorsal root ganglion. ${ }^{46}$ S100B also enhances the survival of chick telencephalic neurons ${ }^{47}$ and embryonic motor neurons. ${ }^{48}$ In addition, it has been reported that $\mathrm{S} 100 \mathrm{~B}$ protects hippocampal neurons from damage induced by glucose deprivation..$^{49}$ Kligman \& Marshak ${ }^{43}$ proposed a model which states that glial-derived S100B released into extracellular spaces exerts a trophic influence on the development of neighboring neurons.
In support of this model, release of S100B from cultured cells has been shown to occur. ${ }^{50,51}$ In addition, evidence has been obtained which implicates an autocrine, or self regulating function for S100B. For example, glial cells in which S100B production was inhibited by specific antisense techniques exhibited decreased cell growth. ${ }^{52}$ Furthermore, addition of S100B to glial cultures leads to increases in expression of growth-associated proto-oncogenes, c-myc and c-fos, incorporation of $[3 \mathrm{H}]$ thymidine, and cell number. ${ }^{53}$

\section{Distribution of SI 00A in vestibular end organs}

When sections of the vestibular end organs were fixed with $4 \%$ paraformaldehyde, S100A1 immunoreactivity was localized to the basal region of vestibular epithelium, in the crista ampullaris and the utricular maculae. Fixation with the precipitating fixative, revealed a different pattern of localization. Not only was the basal area immunoreactive, but the apical regions of the epithelium in the vestibular end organs were also positive for S100A1. The basal localization may be due to membrane-bound or membrane-associated population of S100A1 since these types of proteins are better retained in aldehyde fixed tissues. Membrane-associated proteins may be associated with intracellular structures, such as mitochondria membranes or cisternae of the endoplasmic reticulum, or may be associated with plasma membrane proteins. Thus, as is the case for cardiac muscle, ${ }^{54}$ there appears to be a fraction of S100A1that is extracted from tissue during processing. The S100A1 located in the apical region of supporting cells that is lost during fixation in our study may represent S100A1 interacting with target proteins located in this region of the cell. In supporting cells, components of the cytoskeleton are located in this region and may contain target proteins for S100A1. The additional quantity of S100A1 in the apical region of the vestibular epithelium revealed with the precipitating fixative may well correspond to a soluble cytoplasmic fraction of S100A1. These proteins may be associated with components of the cytoskeleton. During aldehyde fixation, soluble proteins can be lost. ${ }^{37}$ This may indicate different functions for the S100A1 in the basal versus apical regions of the cell. The initial steps of sensory transduction occur in the apical region of vestibular hair cells, and the S100A1 located in this region may help to modulate the transduction process.

\section{Possible functions of SIOOAI and SIOOB in vestibular end organs}

The S100 subunits have been localized to a number of tissues and cell types. ${ }^{36}$ For example, in stratified columnar epithelia of the endocervical duct and ductus epididymis, S100A1 is located in the columnar cells, whereas S100B is associated with the basal cells, a population of cells capable of differentiation into columnar cells. Haimoto et al. ${ }^{36}$ suggested that during the change from undifferentiated basal cells to the differentiated columnar cells, a corresponding switch occurs from expression of S100A1 to expression of S100B. In support of the idea that more than one form of S100 may be involved in hair cell regulation, $\mathrm{S} 100 \mathrm{~A} 1, \mathrm{~A} 5$ and $\mathrm{A} 6$ have been shown to be expressed at different times during the development of the dog cochlea. ${ }^{55}$ Of the newer forms of S100 proteins identified, some have target proteins or actions that may be of particular importance in the functional regulation of vestibular hair cells. For example, during normal epidermal differentiation, as well as, during epidermal growth in psoriasis, ${ }^{16} \mathrm{~S} 100 \mathrm{~A} 7$ changes from a cytosolic to a plasma membranebound form. The cytosolic form is presumed to be secreted (or released during cell death) acting as a chemotaxic agent for epidermal 
growth and differentiation. In addition, $\mathrm{S} 100 \mathrm{~B}$ binds to and regulates the calcium-dependent activity of a membrane-bound guanylate cyclase protein in bovine retina. ${ }^{56,57}$ Perhaps in a manner similar to that reported in the mammalian retina, the cytoplasmic portion of S100A1 in the apical region of the vestibular hair cells may be involved in modulating sensory transduction by binding to a plasma membranebound protein.

As is the case in the central nervous system, S100 may be involved in development and maintenance of sensory hair cells or peripheral nerve pathways in the vestibular end organs. In addition, this protein may play a role in hair cell regeneration by stimulating proliferative activities in certain cell types, such as supporting cells of the vestibular epithelium. This suggestion of S100 involvement in hair cell regeneration is supported by known characteristics of extracellularly located S100 obtained from studies on glial cells. For instance, mRNA for S100B does not code for a secretion signal sequence, suggesting that $\mathrm{S} 100 \mathrm{~B}$ is not normally secreted by glial cells. ${ }^{58}$ Instead it may be released in response to cell damage and lysis. In vestibular sensory epithelia of the utricular maculae of guinea pigs and humans, treatment with ototoxic levels of aminoglycoside antibiotics (neomycin or gentamicin) results in a dramatic loss of sensory hair cells. Replacement hair cells appear to arise from proliferating supporting cells..$^{59,60}$ Supporting cells perform "gliallike" functions in the vestibular end organs, i.e., they are necessary for the maintenance and viability of sensory hair cells. Due to their similarities to glial cells, supporting cells may also respond to S100 in a manner similar to that seen in glial cells.

By analyzing the data from this study, we can also comment on the type of dimerizations that occurs between S100A1 and S100B in the vestibular end organs. S100A1 was exclusively localized to cells in the sensory epithelium of all three types of vestibular end organs (cristae ampullaris, saccular macula and utricular macula). S100A1 was not found in vestibular nerve fibers, vestibular ganglion or nonsensory epithelium lining the membranous labyrinth. Staining for S100A1 in the sensory epithelium was confined to the basal and apical cytoplasmic domains of the supporting cells. In contrast, immunoreactivity for S100B was exclusively localized to vestibular nerve fibers and the vestibular ganglia. There was no noticeable staining of cells in the vestibular epithelium. It is evident that since the distribution of these two S100 proteins was exclusive of each other, the vestibular epithelial cells stained by the S100A1 antibody contain only S100A1-S100A1 homodimers. Likewise, those structures identified by the S100B antibody (vestibular nerve fibers and ganglia) contain only S100B-S100B homodimers. There does not seem to be an identifiable population of cells that contain heterodimers (S100BS100A1). In conclusion, we have described the immunohistochemical localization of S100 in vestibular end organs of the rat. We report on a differential distribution of the two "classic" S100 proteins within this system. S100A1 was associated with epithelial cells of the vestibular end organs, while S100B was associated with the neuronal components of these end organs. The distribution of each S100 protein was mutually exclusive of the other protein. This mutually exclusive distribution suggests different functional roles of these two proteins within the vestibular end organs.

\section{Acknowledgements}

This work was supported by NIMH/MRISP Grant MH57067-01. I wish to thank Dr. Karen J. Gray for her help in collecting data used in the preparation of this paper.

\section{Conflict of interest}

Author declares that there is no conflict of interest.

\section{References}

1. Moore BM. A soluble protein characteristic of the nervous system Biochem Biophys Res Commun. 1965;19(6):739-744.

2. Persechini A, Moncrief ND, Kretsinger RH. The EF-hand family of calcium-modulated proteins. Trends Neurosci. 1989;12(11):462-467.

3. Donato R. Perspectives in S-100 protein biology. Cell Calcium. 1991;12(10):713-726.

4. Donato R. Functional roles of S100 proteins, calcium-binding proteins of the EF-hand type. Biochim Biophys Acta. 1999;1450(3):191-231.

5. Engelkamp D, Schäfer BW, Mattei MG, et al. Six S100 genes are clustered on human chromosome 1q21: Identification of two genes coding for the two previously unreported calcium-binding proteins S100D and S100E. Proc Natl Acad Sci USA. 1993;90(14):6547-6551.

6. Ridinger K, Ilg EC, Niggli FK, et al. Clustered organization of S100 genes in human and mouse. Biochim Biophys Acta. 1998;1448(2):254-263.

7. Allore R, O'Hanlon D, Price R, et al. Gene encoding the $\beta$ subunit of S100 protein is on chromosome 21: Implication for down syndrome. Science. 1988;239(4845):1311-1313.

8. Gazzolo D, Bruschettini M, Corvino V, et al. Amniotic fluid levels of S100B protein in normal and trisomy-21 foetuses. Clin Chim Acta. 2003;330(1-2):131-133.

9. Mito T, Becker LE. Developmental changes of S-100 protein and glial fibrillary acidic protein in the brain of Down syndrome. Exp Neurol. 1993;120(2):170-176.

10. Takashima S, Iida K, Mito $\mathrm{T}$, et al. Dendritic and histochemical development and ageing in patients with Down's syndrome. $J$ Intellect Disabil Res. 1994;38(pt 3):265-273.

11. Griffin WS, Stanley LC, Ling C, et al. Brain interleukin 1 and S-100 immunoreactivity are elevated in Down syndrome and Alzheimer disease. Proc Natl Acad Sci USA. 1989;86(19):7611-7615.

12. Van Eldik LJ, Griffin WS. S100 beta expression in Alzheimer's disease: relation to neuropathology in brain regions. Biochim Biophys Acta. 1994;1223(3):398-403.

13. Balmain N, Moutahir F, Heizmann CW, et al. Immunolocalization of $\mathrm{S} 100 \mathrm{~A} 2$ calcium-binding protein in cartilage and bone cells. Cell Mol Biol. 2003;49(4):485-486.

14. Schafer BW, Heizmann CW. The S100 family of EF-hand calciumbinding proteins: functions and pathology. Trends Biochem Sci. 1996;21(4):134-140.

15. Eue I, Konig S, Pior J, et al. S100A8, S100A9 and the S100A8/A9 heterodimer complex specifically bind to human endothelial cells: identification and characterization of ligands for the myeloid-related proteins S100A9 and S100A8/A9 on human dermal microvascular endothelial cell line-1 cells. Int Immunol. 2002;14(3):287-297.

16. Broome AM, Ryan D, Eckert RL. S100 protein subcellular localization during epidermal differentiation and psoriasis. J Histochem Cytochem. 2003;51(5):675-685.

17. TomasA,Moss SE. Calcium-and cell cycle-dependentassociation ofannexin 11 with the nuclear envelope. J Biol Chem. 2003;278(22):20210-20216.

18. Yamashita N, Ilg EC, Schafer BW, et al. Distribution of a specific calciumbinding protein of the S100 protein family, S100A6 (calcyclin), in subpopulations of neurons and glial cells of the adult rat nervous system. $J$ Comp Neurol. 1999;404(2):235-257. 
19. Ali SM, Geisow MJ, Burgoyne RD. Arole for calpactin in calcium-dependent exocytosis in adrenal chromaffin cells. Nature. 1989;340(6231):313-315.

20. Drust DS, Creutz CE. Aggregation of chromaffin granules by calpactin at micromolar levels of calcium. Nature. 1988;331(6151):88-91.

21. Klee CB. Ca2+-dependent phospholipid- (and membrane-) binding proteins. Biochem. 1988;27(18):6645-6653.

22. Fanò G, Marsili V, Angelella $\mathrm{P}$, et al. S-100a0 protein stimulates $\mathrm{Ca} 2+$ induced $\mathrm{Ca} 2+$ release from isolated sarcoplasmic reticulum vesicles. FEBS Lett. 1989;255(2):381-384.

23. Sorci G, Riuzzi F, Arcuri C, et al. S100B protein in tissue development, repair and regeneration. World J Biol Chem. 2013;4(1):1-12.

24. Krawczyk A, Rycerz K, Szalak R, et al. Immunoreactivity of S100ק protein in the hippocampus of chinchilla. Bull Vet Inst Pulawy. 2014;58(1):105-109.

25. Park ES, Park CI, Choi KS, et al. Over-expression of S100B protein in children with cerebral palsy or delayed development. Brain Dev. 2004;26(3):190-196.

26. Rothermundt M, Ponath G, Glaser T, et al. S100B serum levels and longterm improvement of negative symptoms in patients with schizophrenia. Neuropsychopharmacology. 2004;29(5):1004-1011.

27. Dietrich DE, Hauser U, Peters M, et al. Target evaluation processing and serum levels of nerve tissue protein S100B in patients with remitted major depression. Neurosci Lett. 2004;354(1):69-73.

28. Akhisaroglu M, Manev R, Akhisaroglu E, et al. Both aging and chronic fluoxetine increase $\mathrm{S} 100 \mathrm{~B}$ content in the mouse hippocampus. Neuroreport. 2003;14(11):1471-1473.

29. Muneoka KT, Borella A, Whitaker Azmitia PM. Transient expression of S-100beta immunostaining in developing thalamus and somatosensory cortex of rat. Brain Res Dev Brain Res. 2003;142(1):101-104.

30. Dietrich MO, Tort AB, Schaf DV, et al. Increase in serum $\mathrm{S} 100 \mathrm{~B}$ protein level after a swimming race. Can J Appl Physiol. 2003;28(5):710-716.

31. Gonzalez Martinez T, Perez Pinera P, Diaz Esnal B, et al. S-100 proteins in the human peripheral nervous system. Microsc Res Tech. 2003;60(6):633-638.

32. Daub B, Schroeter M, Pfitzer G, et al. Expression of members of the S100 $\mathrm{Ca} 2+-$ binding protein family in guinea-pig smooth muscle. Cell Calcium. 2003;33(1):1-10.

33. Most P, Bernotat J, Ehlermann P, et al. S100A1: a regulator of myocardia contractility. Proc Natl Acad Sci USA. 2001;98(24):13889-13894.

34. Most P, Boerries M, Eicher C, et al. Extracellular S100A1 protein inhibits apoptosis in ventricular cardiomyocytes via activation of the extracellular signal-regulated protein kinase 1/2 (ERK1/2). J Biol Chem. $2003 ; 278(48): 48404-48412$.

35. Sorci G, Riuzzi F, Agneletti AL, et al. S100B inhibits myogenic differentiation and myotube formation in a RAGE-independent manner. Mol Cell Biol. 2003;23(14):4870-4881.

36. Haimoto H, Hosoda S, Kato K. Differential distribution of immunoreactive $\mathrm{S} 100 \alpha$ and $\mathrm{S} 100 \beta$ proteins in normal nonnervous human tissues. Lab Invest. 1987;57(5):489-498.

37. Brown GG. An Introduction to histotechnology: a manual for the student practicing technologist, and resident-in-pathology. New York: AppletonCentury-Crofts; 1978. 453p.

38. Reydon JL, Smith CA. The ultrastructure of normal and otosclerotic human stapes (preliminary studies). Laryngoscope. 1968;78(1):95-121.
39. Foster JD, Drescher MJ, Khan KM, et al. Immunohistochemical localization of S-100 proteins in the saccule of the rainbow trout, (Salmo gairdneri R). Hear Res. 1993;68(2):180-188.

40. Foster JD, Drescher MJ, Hatfield JS, et al. Immunohistochemical localization of S-100 proteins in auditory and vestibular end organs of the mouse and hamster. Hear Res. 1994;74(1-2):67-76.

41. Astic L, Pellier Monnin V, Godinot F. Spatio-temporal patterns of ensheathing cell differentiation in the rat olfactory system during development. Neuroscience. 1998;84(1):295-307.

42. Locher $\mathrm{H}$, de Groot JCMJ, van Iperen $\mathrm{L}$, et al. Distribution and development of peripheral glial cells in the human fetal cochlea. PLOS One. 2014;9(1):e88066.

43. Kligman D, Marshak DR. Purification and characterization of a neurite extension factor from bovine brain. Proc Natl Acad Sci USA. 1985;82(20):7136-7139.

44. Azmitia EC, Dolan K, Whitaker Azmitia PM. S 100B but not NGF, EGF, insulin or calmodulin is a CNS serotonergic growth factor. Brain Res. 1990;516(2):354-356.

45. Marshak DR. S100 beta as a neurotrophic factor. Prog Brain Res. 1990;86:169-181.

46. Van Eldik LJ, Christie Pope B, Bolin LM, et al. Neurotrophic activity of $\mathrm{S}-100 \beta$ in cultures of dorsal root ganglia from embryonic chick and fetal rat. Brain Res. 1991;542(2):280-285.

47. Winningham Major F, Whetsell WO, Van Eldik LJ. Recombinant neurotrophic factor promotes survival and stimulates neurite outgrowth in nervous system cultures. J Cell Biol. 1989;107:729a.

48. Bhattacharyya A, Oppenheim RW, Prevette D, et al. S100 is present in developing chicken neurons and Schwann cells and promotes motor neuron survival in vivo. J Neurobiol. 1992;23(4):451-466.

49. Barger SW, Van Eldik LJ, Mattson MP. S100 beta protects hippocampal neurons from damage induced by glucose deprivation. Brain Res. 1995;677(1):167-170.

50. Ishikawa $H$, Nogami $H$, Shirasawa N. Novel clonal strains from adult rat anterior pituitary producing S-100 protein. Nature. 1983;303(5919):711-713.

51. Suzuki F, Kato K, Kato T, et al. S 100 protein in clonal astroglioma cells is released by adrenocorticotropic hormone and corticotropin like intermediate lobe peptide. J Neurochem. 1987;49(5):1557-1563.

52. Selinfreund RH, Barger SW, Welsh MJ, et al. Antisense inhibition of glial S100 beta production results in alterations in cell morphology, cytoskeletal organization, and cell proliferation. J Cell Biol. 1990;111(5 pt 1):2021-2028.

53. Selinfreund RH, Barger SW, Pledger WJ, et al. Neurotrophic protein S100 beta stimulates glial cell proliferation. Proc Natl Acad Sci USA. 1991;88(9):3554-3558.

54. Haimoto H, Kato K. S100a0 (alpha alpha) protein in cardiac muscle. Isolation from human cardiac muscle and ultrastructural localization. Eur J Biochem. 1988;171(1-2):409-415.

55. Coppens AG, Kiss R, Heizmann CW, et al. Immunolocalization of the calcium binding S100A1, S100A5 and S100A6 proteins in the dog cochlea during postnatal development. Brain Res Dev Brain Res. 2001;126(2):191-199.

56. Rambotti MG, Giambanco I, Spreca A, et al. S100B and S100A1 proteins in bovine retina: their calcium-dependent stimulation of a membranebound guanylate cyclase activity as investigated by ultracytochemist. Neuroscience. 1999;92(3):1089-1101. 
57. Sitaramayya A. Calcium-dependent activation of guanylate cyclase by S100b. Adv Exp Med Biol. 2002;514:389-398.

58. Barger SW, Van Eldik LJ. S100ß stimulates calcium fluxes in glial and neuronal cells. J Biol Chem. 1992;267(14):9689-9694.

59. Forge A, Li L, Corbin JT, et al. Ultrastructural evidence for hair cell regeneration in the mammalian inner ear. Science. 1993;259(5101):1616-1619

60. Warchol ME, Lambert PR, Goldstein BJ, et al. Regenerative proliferation in inner ear sensory epithlia from adult guinea pigs and humans. Science. 1993;259(5101):1619-1622. 